\title{
ANALISIS KEPUASAN PELANGGAN TERHADAP JASA PENGGILINGAN PADI (Studi Kasus Penggilingan Padi Tunas Karya Desa Persil Raya, Kecamatan Seyuran Hilir, Kabupaten Seruyan)
}

\section{Analysis of Customer Satisfaction on Rice Milling Services (Case Study of Rice Mill Milling Tunas Karya in Persil Raya Village, Seyuran Hilir District, Seruyan Regency)}

\author{
Anggun Erli Santika ${ }^{1}$, Tirsa Neyatri Bandrang ${ }^{1^{*}}$ \\ 1Politeknik Seruyan, Jl A.Yani, KualaPembuang, Seruyan Hilir Kabupaten \\ Seruyan, Kalimatan Tengah, Indonesia. \\ *Email: tneyatri.poltes@gmail.com
}

\begin{abstract}
ABSTRAK
Penelitian ini bertujuan menganalisis karakteristik pelanggan dan menganalisis kepuasan pelanggan Jasa Penggilingan Padi Tunas Karya, karena pelanggan yang merasa puas merupakan asset penting bagi tempat usaha Penggilingan Padi Tunas Karya. Dalam melakukan penelitian ini, untuk tujuan pertama menggunakan metode analisis deskriptif yakni untuk melihat karakteristik pengunjung dan untuk tingkat kepuasan konsumen di Penggilingan Padi Tunas Karya menggunakan dua metode, yakni Customer Satisfaction Index (CSI) digunakan untuk menentukan kepuasan pelanggan secara menyeluruh dengan pendekatan yang mempertimbangkan tingkat kepentingan dari variabel-variabel yang diukur, dan Importance Perfoemance Analysis (IPA) digunakan untuk mengetahui keadaan masing-masing variabel dari faktor-faktor kepuasan ditinjau dari segi tingkat kepentingan dan tingkat kinerja atribut, serta menggunakan diagram kartesius dan yang terdapat pada empat kuadrat. Hasil uji realibilitas untuk butir soal evaluasi kepentingan dan evaluasi kinerja menunjukan nilai yang lebih besar dari nilai kritis yang ditoleransi yaitu 0,81 untuk butir soal evaluasi kepentingan dan 0,86 untuk butir soal evaluasi kinerja. Hasil penelitian berdasarkan metode Importance Performance Analysis (IPA) pada kuadran I terdapat 1 atribut, Pada kuadran II terdapat 11 atribut, Kuadran III
\end{abstract}


terdapat 4 atribut, Pada kuadran IV terdapat 3 atribut. Berdasakan metode Customer Satisfaction Index (CSI) posisi pada tingkat kepuasan pelanggan berada pada tingkat sangat puas dengan hasil 0,85 yang didasarkan pada tabel indeks kepuasan pelanggan untuk atribut-atribut yang telah diuji.

Kata Kunci: Penggilingan Padi, Analisis Deskriptif, Performance Analysis (IPA), Customer Satisfaction Index (CSI)

\begin{abstract}
This study aims to analyze customer characteristics and analyze customer satisfaction in Tunas Karya Rice Milling Services. Because a satisfied customer is an important asset for the Tunas Karya Rice Mill business. In conducting this research, for the first purpose using descriptive analysis method, namely to see the characteristics of visitors and for the level of customer satisfaction at Tunas Karya Rice Mill using two methods, namely the Customer Satisfaction Index (CSI) used to determine overall customer satisfaction with an approach that considers the level the importance of the measured variables, and Importance Performance Analysis (IPA) is used to determine the state of each variable from the satisfaction factors in terms of importance level and attribute performance level, as well as using Cartesian diagrams and those contained in four squares. The results of the reliability test for the interest evaluation and performance evaluation items showed a value greater than the tolerable critical value, namely 0.81 for the evaluation of interest items and 0.86 for the performance evaluation items. The results of the study are based on the Importance Performance Analysis (IPA) method in quadrant I there is 1 attribute, in quadrant II there are 11 attributes, Quadrant III there are 4 attributes, in quadrant IV there are 3 attributes. Based on the Customer Satisfaction Index (CSI) method, the position on the level of customer satisfaction is at a very satisfied level with a result of 0.85 which is based on the customer satisfaction index table for the attributes that have been tested.
\end{abstract}

Keywords: Rice Milling, Descriptive Analysis, Performance Analysis (IPA), Customer Satisfaction Index (CSI) 


\section{PENDAHULUAN}

Beras merupakan kebutuhan dasar bagi kehidupan manusia baik ditinjau dari segi fisiologis, phisikologis, sosial maupun antropologis. Bagi masyarakat indonesia, beras menjadi komoditas yang sangat penting, tidak saja dilihat dari sisi produsen tetapi juga dari sisi konsumen. Sebelum menjadi beras, padi akan melalui beberapa tahap pascapanen yaitu: pemanenan padi, penyimpanan padi, perontokan padi, pengeringan padi, pengilingan gabah hingga menjadi beras. Masalah utama yang dihadapi petani dari proses pascapanen padi tersebut adalah kehilangan hasil yang cukup tinggi yang dikarenakan ada beras yang menjadi remuk ketika digiling. Besarnya jumlah penggilingan padi yang menyebar hampir merata di seluruh daerah sentra produksi padi di Indonesia ini menggambarkan bahwa Penggilingan padi memiliki peran yang sangat penting, dibidang Pertanian.

Supply beras nasional dituntut untuk dapat memberikan kontribusi dalam penyediaan beras, baik dari segi kuantitas maupun kualitas yang mendukung ketahanan pangan nasional, maka Penggilingan padi yang merupakan tempat pertemuan antara produksi, pasca panen, pengolahan dan pemasaran gabah/beras sehingga merupakan mata rantai penting untuk menghasilkan beras/gabah secara maksimal dan baik (Arsyad, dkk., 2015). Besarnya jumlah penggilingan padi yang tersebar di sejumlah daerah tidak menjamin kualitas beras yang dihasilkan (Asmawati, 2009). Proses pengolahan gabah menjadi beras merupakan suatu proses yang terjadi pada penggilingan padi dengan batas kadar air 13-14\%. Umumnya proses penggilingan padi dapat dipisahkan antara pengolahan gabah sampai menjadi beras pecah kulit (BPK) dan proses penyosohan yakni pengolahan beras pecah kulit menjadi beras sosoh. Pemisahan proses ini menggunakan alat yang terpisah yakni husker (pemecah kulit) dan whitener (pemutih/penyosoh). Berdasarkan penggunaan alat pada penggilingan secara umum, penggilingan padi cenderung untuk meningkatkan mutu, terutama pada penggilingan yang berskala kecil (Sudirman, 2011).

Penggilingan padi merupakan salah satu unsur dalam penanganan pascapanen yang memerlukan proses penanganan dan pengolahan. Ketersediaan panen yang melimpah menimbulkan ketidakseimbangan dengan 
output beras yang dihasilkan dikarenakan banyak tingkat kehilangan pada proses penanganan pascapanen yang masih menggunakan alat tradisional. Dengan adanya permasalahan tersebut maka sebaiknya pelaku usaha mengembangkan penggunaan teknologi dalam proses penggilingan padi, yaitu dengan cara menggunakan mesin dengan teknologi yang lebih efisien. Dalam hal ini untuk membuat pelaku usaha agar lebih baik dalam menggunakan mesin penggilingan padi, sebaiknya pemerintah menunjang itu memberikan pelatihan penggunaan mesin padi tersebut agar pelaku usaha dapat dengan mahir untuk menggunakannya, sehingga pengolahan beras yang dihasilkan lebih optimal.

Beras yang dijual di tempat penggilingan padi adalah beras yang diolah secara alami oleh para petani mulai dari peprosesan benih menjadi padi hingga dari padi menjadi beras, yang mana beras yang dihasilkan tersebut benar - benar alami, tidak menggunakan bahan kimia untuk mendapatkan hasil yang maksimal. Karena hal itu pula yang menjadikan masyarakat memiliki minat untuk membeli langsung beras yang dijual dipenggilingan padi ataupun mereka menggiling sendiri padi yang mereka miliki selain hal itu kenapa masyarakat lebih meminati beras hasil yang digiling secara langsung dikarenakan harga jual yang lebih murah.

Pembangunan sektor pertanian yang memiliki nilai strategis, antara lain dalam memenuhi kebutuhan pangan yang terus meningkat akibat bertambahnya jumlah penduduk, peningkatan rata-rata pendapatan penduduk, luasnya penciptaan lapangan pekerjaan dan Usaha Jasa Penggilingan Padi yang bergerak disektor pertanian merupakan bagian dari salah satu pembangunan sektor pertanian tersebut serta semakin meningkatkan kesadaran gizi masyarakyat. Bertempat di Kabupaten Seruyan, Kecamatan Seruyan Hilir khususnya di Desa Persil Raya usaha Jasa Penggilingan Padi merupakan salah satu cabang dari sektor pertanian yang sedang terus berjalan usahanya. Banyak terdapat usaha dibidang pertanian di Kecamatan Seruyan Hilir, salah satunya adalah tempat usaha Jasa Penggilingan Padi. Adapun yang berdiri di Kecamatan Seruyan Hilir khususnya di Desa Persil Raya juga sangat pesat untuk perkembangan usaha jasa tempat penggilingan padi ini. 
Tabel 1. Data Penggilingan Padi di Desa Persil Raya

\begin{tabular}{lcc}
\hline \multicolumn{1}{c}{ Nama Penggilingan Padi } & $\begin{array}{c}\text { Kapasitas Produksi } \\
\text { Perhari (ton) }\end{array}$ & Alamat \\
\hline Penggilingan Padi ATI & 1 ton & Sungai Mitak \\
\hline Penggilingan Padi Tunas Karya & 2 ton & Rt 001 \\
\hline Penggilingan Padi Dolah & 2 ton & Rt 003 \\
\hline Penggilingan Padi Karya Keluarga & 2,5 ton & Rt 001 \\
\hline Penggilingan Padi Karya Mandiri & 1 ton & Rt 003 \\
\hline
\end{tabular}

Berdasarkan Tabel 1 dapat diketahui kapasitas produksi perhari masing - masing tempat usaha penggilingan padi, dimana untuk penggilingan padi ATI memiliki kapasitas satu hari produksi 1 ton begitu juga untuk penggilingan padi Karya Mandiri, penggilingan padi Dolah memiliki kapasitas perharinya 2 ton perproduksi, tetapi untuk ke tiga tempat usaha jasa penggilingan padi ini tidak buka setiap tiap hari kecuali padi yang akan mereka giling sudah sampai kapasitas yang mereka tentukan maka mereka akan memproduksi, berbeda dengan diwaktu musim panen dimana disaat musim panen produksi mereka dalam satu hari dapat dipastikan satu sampai dua ton. Untuk penggilingan padi Tunas Karya dalam satu hari produksi sebanyak dua ton yang mana penggilingan padi tunas karya ini buka setiap hari dan jarang libur terkecuali untuk hari - hari yang memang diliburkan karena ada kepentingan atau acara lain, penggilingan padi ini juga memiliki pelanggan yang tetap. Tempat penggilingan padi yang terakhir adalah tempat penggilingan padi Karya Keluarga dimana penggilingan padi ini adalah tempat penggilingan padi yang paling lama berdiri diantara yang lain, yang memiliki kapasitas produksi dua setengah ton perharinya, untuk jam operasi usaha bejalan beliau membatasi dari jam 8 pagi sampai jam 12 siang dan masuk lagi dari jam 2 siang sampai jam 4 sore, dimana beliau juga memiliki pelanggan tetap.

Mengukur kepuasan pelanggan, dapat mengetahui cara membuat pelanggan puas terhadap suatu jasa atau produk yang mereka pakai, serta yang menyebabkan pelanggan puas terhadap jasa atau produk yang mereka pakai dan untuk tetap terus membuat pelanggan bertahan melakukan pembelian atau pemakaian jasa, maka perlu mengetahui cara untuk tetap mempertahankan 
pelanggan dengan tujuan pelanggan tetap setia dan senang membeli atau memakai jasa dari, untuk membuat usaha akan terus berkembang dan pelangganpun akan terus berdatangan serta menggunakan ulang jasa yang dijual. Pengukuran kepuasan pelanggan dapat mengetahui cara yang bisa membuat pelanggan merasa puas dan akan terus menjadi pelanggan tetap, penelitian mengukur kepuasan pelanggan dapat digunakan untuk membantu melakukan perbaikan dari segi kualitas pelayanan dan hasil produk, agar membuat usaha tetap berjalan dan lebih maju lagi

Berdasarkan hasil survey di lapangan, diperoleh tempat penggilingan padi yang aktif produksi 2 ton perhari yaitu penggilingan padi Tunas Karya. Pengambilan tempat penggilingan padi yang akan dijadikan objek penelitian ini didasarkan melalui beberapa faktor, seperti penggilingan padi Tunas Karya mampu bersaing dengan penggilingan padi yang lebih dahulu berdiri seperti tempat Penggilingan Padi Karya Keluarga yang sudah memiliki pelanggan tetap. Pelanggan yang menggiling padinya di penggilingan padi Tunas Karya tidak hanya yang berada disekitar wilayah tempat usaha berdiri saja, tetapi yang dari luar wilayah desa persil raya pun juga ada, bahkan informasi yang penulis dapat dari narasumber jika ada pelanggan penggilingan padi Karya Keluarga yang berpindah menjadi pelanggan penggilingan padi Tunas Karya.

Pentingnya melakukan penelitian pengukur kepuasan konsumen terhadap penggilingan padi Tunas Karya karena untuk mengetahui sejauh mana para pelanggan penggilingan padi Tunas Karya merasakan puas terhadap jasa yang dijual oleh penggilingan padi. Berdasarkan latar belakang itulah maka perlu dilakukan penelitian mengenai "Analisis Kepuasan Pelanggan Terhadap Jasa Penggilingan Padi (Studi Kasus Penggilingan Padi Tunas Karya Desa Persil Raya, Kecamatan Seyuran Hilir, Kabupaten Seruyan)".

\section{METODOLOGI}

\section{Lokasi dan Waktu Penelitian}

Lokasi penelitian dilakukan di Penggilingan Padi Tunas Karya, Desa Persil Raya, Kecamatan Seruyan Hilir, Kabupaten Seruyan. Pemilihan tempat penggilingan padi yang akan dijadikan objek penelitian ini dilakukan secara 
sengaja dengan pertimbangan bahwa Penggilingan Padi Tunas Karya merupakan salah satu penggilingan padi yang menerima jasa penggilingan Padi dan menyediakan beras untuk konsumen yang ada di Kecamatan Seruyan Hilir, tidak hanya itu juga didasarkan melalui beberapa faktor, seperti penggilingan padi mampu bersaing dengan penggilingan padi yang lebih dahulu berdiri, waktu beroperasi tempat usaha setiap hari, dalam satu tahun hampir tidak pernah tutup atau libur. Waktu penelitian ini dilakukan pada Bulan April sampai dengan Bulan Mei 2020.

\section{Metode Analisis}

Menganalisis kepuasan pelanggan Penggilingan Padi Tunas Karya menggunakan 2 metode analisis data, yaitu metode analisis Impotance Performance Analysis (IPA) dan Customer Satisfaction Index (CSI). Analisis Importance Performance Analysis (IPA) dimaksudkan untuk mengetahui keadaan masing-masing variabel dari faktor-faktor kepuasan ditinjau dari segi kepentingan dan kinerja. Dimana pengukuran variabel dari masing-masing tingkat kepentingan dan tingkat kinerja menggunakan skala likert, adapun panduan pengukuran menggunakan skala likert yaitu: Tingkat kepentingan, sangat penting $=5$, penting $=4$, netral $=3$, tidak penting $=2$, sangat tidak penting $=$ 1, dan tingkat kinerja, sangat baik $=5$, baik $=4$, netral $=3$, tidak baik $=2$, sangat tidak baik $=1$. Analisis tingkat kepentingan dan tingkat kinerja Importance Performance Analysis (IPA) menggunakan diagram kartesius dimana penilaian kepentingan pelanggan ditunjukan dengan huruf $Y$, sementara penilaian kinerja perusahaan ditunjukan oleh huruf $X$. Untuk memenuhi maksud maka langkah-langkah yang ditempuh adalah sebagai berikut.

a. Sebagai indikator skala ukuran kuantitatif untuk tingkat kepentingan menurut persepsi pelanggan dan tingkat kinerja secara nyata dinyatakan dalam bentuk tanggapan pelanggan terhadap kepuasan berupa skala likert. Skala ini memungkinkan responden untuk dapat mengekspresikan intensitas perasaan mereka terhadap karakteristik suatu produk dengan menentukan jumlah skor dari setiap variabel $X$ dan $Y$. Skor ini diperoleh dengan mengalikan seluruh frekuensi data dengan bobotnya (Simamora, 
2002). Total penilaian tingkat kepentingan dan tingkat kinerja masing-masing atribut diperoleh dengan cara menjumlahkan hasil perkalian bobot masing-masing skala dengan jumlah responden yang memilih skala tersebut.

b. Selanjutnya dilakukan pembagian jumlah skor dengan banyaknya responden, hasilnya berupa skor rata-rata tingkat kepentingan $(\mathrm{Y})$ dan skor rata-rata tingkat kinerja $(\mathrm{X})$. Dalam penyederhanaan rumus, maka untuk setiap faktor yang mempengaruhi kepuasan pelanggan adalah sebagai berikut:

$$
X=\frac{\Sigma X_{1}}{n} \quad Y=\frac{\Sigma Y_{1}}{n}
$$

Keterangan:

$\mathrm{X}=$ Skor rata-rata tingkat kinerja atribut pada setiap variabel Penggilingan Padi Tunas Karya

$\mathrm{Y} \quad=$ Skor rata-rata tingkat kepentingan atribut pada setiap variabel Penggilingan Padi Tunas Karya

$\Sigma X_{1} \quad=$ Total skor tingkat kinerja dari seluruh responden

$\Sigma Y_{1} \quad=$ Total skor tingkat kepentingan dari seluruh responden

$\mathrm{n} \quad=$ Jumlah responden 
c. Selanjutnya skor rata-rata tingkat kepentingan dan kinerja dianalisis pada diagram kartesius.

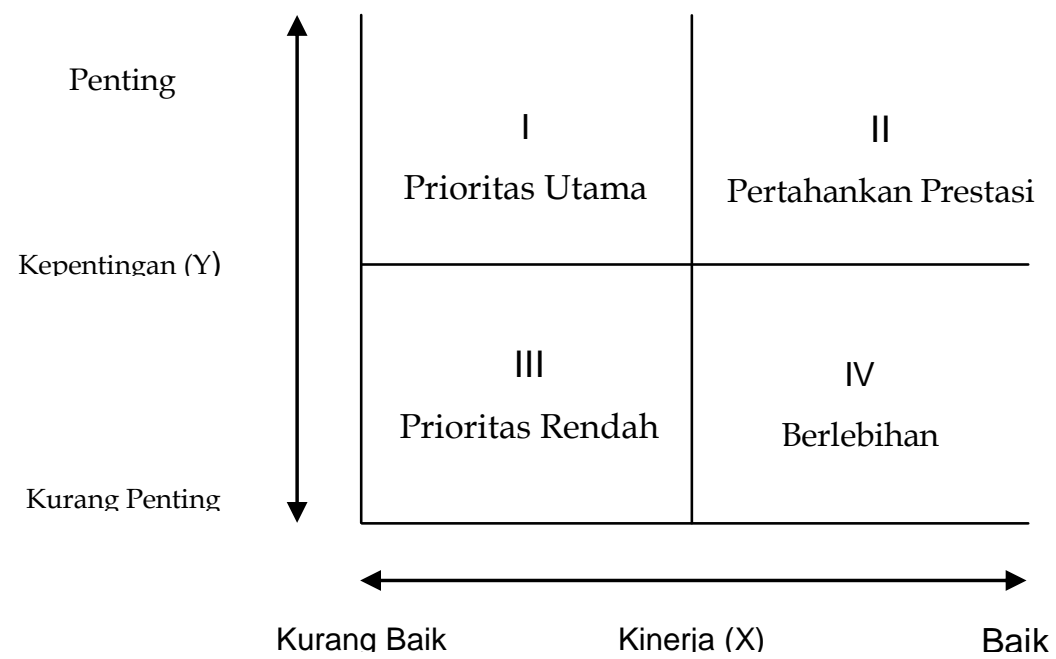

Gambar 1. Diagram Cartesius Importance Performance Analysis

Dapat dilihat dari diagram tersebut, dapat dirumuskan strategi yang dilakukan berkaitan dengan posisi masing-masing atribut pada ke empat kuadran tersebut yang dapat dijelaskan sebagai berikut:

a) Kuadran I (Prioritas Utama), posisi ini memuat atribut-atribut pada setiap variabel yang dianggap penting oleh pelanggan namun pada kenyataannya kinerja dari variabel ini belum sesuai dengan yang diharapkan. Artinya tingkat kepuasan yang diperoleh pelanggan masih sangat rendah dan perlu dilakukan perbaikan terus-menerus.

b) Kuadran II (Pertahankan Prestasi), posisi ini memuat atribut-atribut pada setiap variabel yang dianggap penting oleh pelanggan telah dilaksanakan dengan baik dan dapat memuaskan pelanggan.

c) Kuadran III (Prioritas Rendah), posisi ini memuat atribut-atribut pada setiap variabel yang dianggap kurang penting pengaruhnya bagi pelanggan, dan pada kenyataannya juga kinerjanya kurang istimewa. Perbaikan dan peningkatan kinerja variabel-variabel ini dapat dipertimbangkan kembali karena pengaruhnya kecil terhadap pelanggan. 
d) Kuadran IV (Berlebihan), posisi ini memuat atribut-atribut pada setiap variabel yang dianggap kurang penting pengaruhnya bagi pelanggan, namun pelaksanaannya telah dilaksanakan dengan sangat baik. Kinerja variabel-variabel ini dapat dihemat karena dapat menghemat biaya.

Customer Satisfaction Index (CSI) digunakan untuk menentukan tingkat kepuasan pelanggan secara menyeluruh dengan pendekatan yang mempertimbangkan tingkat kepentingan atribut-atribut pada setiap variabel yang diukur. Menurut Aritonang dan Lebrin (2005) tahap-tahap dalam pengukuran CSI adalah sebagai berikut:

a. Menentukan Mean Importance Score (MIS). Nilai ini berasal dari rata-rata kepentingan tiap pelanggan.

$$
M I S=\frac{\left(\Sigma_{i=I}^{n} Y i\right)}{n}
$$

Dimana: $\mathrm{n}=$ Jumlah pelanggan

$\mathrm{Yi}=$ Nilai kepentingan produk layanan $\mathrm{Y}$ ke-i

b. Membuat Weight Factors (WF). Bobot ini merupakan persentase nilai MIS per atribut pelayanan terhadap total MIS seluruh atribut pelayanan.

$$
W F=\frac{M I S i}{\sum_{i=1}^{p} M I S i} x 100 \%
$$

Dimana: $\mathrm{p} \quad$ = Atribut pelayanan kepentingan ke- $\mathrm{p}$

c. Membuat Weight Score (WS). Bobot ini merupakan perkalian antara WF dengan rata-rata tingkat kepuasan $(\mathrm{x})$ (Mean Satisfaction Score $=$ MSS).

$$
\text { WSi }=\text { WFi } x \text { MSs }
$$


d. Menentukan Customer Satisfaction Index (CSI).

$$
C S I=\frac{\sum_{i=1}^{p} W S i}{H S} \times 100 \%
$$

$$
\begin{aligned}
& \text { Dimana: } \mathrm{p}=\text { Atribut pelayanan kepentingan ke- } \mathrm{p} \\
& \text { HS = (Highest Scale) Skala maksimum yang digunakan }
\end{aligned}
$$

Pada umumnya, apabila nilai CSI di atas 50\% dapat dikatakan jika pelanggan sudah merasa puas terhadap kinerja Penggilingan Padi Tunas Karya namun sebaliknya jika nilai CSI di bawah 50\% pelanggan dikatakan belum puas terhadap kinerja Penggilingan Padi Tunas Karya. Nilai CSI dalam penelitian ini dibagi ke dalam 5 kriteria mulai dari tidak puas sampai dengan sangat puas. Kriteria ini mengikuti modifikasi kriteria yang dilakukan oleh PT. Sucofindo dalam melakukan Survei Kepuasan Pelanggan, adapun kriteria nilai CSI Survei Kepuasan Pelanggan PT. Sucofindo dapat dilihat pada Tabel 2 berikut:

Tabel 2 Kriteria Nilai Customer Satisfaction Index

\begin{tabular}{cc}
\hline Nilai CSI & Kriteria CSI \\
\hline $0,81-1,00$ & Sangat Puas \\
\hline $0,66-0,80$ & Puas \\
\hline $0,51-0,65$ & Cukup Puas \\
\hline $0,35-0,50$ & Kurang Puas \\
\hline $0,00-0,34$ & Tidak Puas \\
\hline
\end{tabular}

Sumber: Riandinia dkk (2006).

\section{HASIL DAN PEMBAHASAN}

\section{Importance Performance Analysis (IPA)}

Importance Performance Analysis (IPA) digunakan untuk mengetahui tingkat kepuasan pelanggan Penggilingan padi Tunas Karya. Kepuasan pelanggan tercapai apabila kinerja perusahaan sesuai dengan tingkat kepentingan pelanggan. Tabel 3 menunjukkan data tingkat kepentingan dan kinerja serta nilai rata-rata masing-masing atribut. 
Tabel 3. Tingkat Kepentingan dan Kinerja Serta Nilai Rata-Rata Atribut

\begin{tabular}{|c|c|c|c|c|}
\hline & \multirow{2}{*}{\multicolumn{2}{|c|}{ Atribut/variabel }} & \multicolumn{2}{|c|}{ Rata-Rata } \\
\hline & & & Kepentingan & Kinerja \\
\hline 1. & \multicolumn{2}{|c|}{ (V1) Harga Jual Jasa Penggilingan Padi } & 4.2 & 4.6 \\
\hline 2. & \multicolumn{2}{|c|}{ (V2) Harga Jual Sesuai Kualitas } & 4.6 & 4.7 \\
\hline \multirow{15}{*}{3.} & \multirow{15}{*}{$\begin{array}{l}\text { Kualitas } \\
\text { Pelayanan }\end{array}$} & (V3) Kecepatan Respon (sigap) & 4.1 & 3.9 \\
\hline & & (V4) Diskon (diatas 1 ton) & 3.8 & 4.0 \\
\hline & & (V5) Kesopanan Merespon & 3.7 & 3.9 \\
\hline & & (V6) Kemahiran & 4.5 & 4.3 \\
\hline & & (V7) Keterampilan & 4.5 & 4.6 \\
\hline & & (V8) Keramahan & 4.5 & 4.6 \\
\hline & & (V9) Kecepatan Bekerja & 4.5 & 4.6 \\
\hline & & (V16) Kejujuran & 4.7 & 4.6 \\
\hline & & (V12) Lokasi & 4.2 & 3.9 \\
\hline & & (V13) Pelayanan via telpon & 4.6 & 3.9 \\
\hline & & (V14) Berperilaku baik & 3.6 & 4.4 \\
\hline & & (V15) Mendengar masukkan & 4.3 & 4.5 \\
\hline & & (V18) Penyediaan tempat penjemuran padi & 4.6 & 4.5 \\
\hline & & (V19) Tingkat kebersihan lingkungan & & \\
\hline & & Penggilingan Padi & 2.9 & 3.8 \\
\hline \multirow[t]{4}{*}{4.} & \multirow{3}{*}{$\begin{array}{l}\text { Kualitas } \\
\text { Produk }\end{array}$} & (V11) Tekstur & 3.4 & 3.5 \\
\hline & & (V10) Warna & 4.2 & 4.6 \\
\hline & & (V17) Kebersihan beras yang dihasilkan & 4.7 & 3.5 \\
\hline & & Rata - Rata & 4.19 & 4.23 \\
\hline
\end{tabular}

Sumber : Referensi ( 2020), diolah.

Importance Performance Analysis (IPA) bertujuan untuk mengetahui tingkat kepuasan pelanggan, kepuasan pelanggan tercapai apabila kinerja perusahaan sesuai dengan tingkat kepentingan pelanggan. Untuk mengetahui tingkat kepuasan pelanggan terhadap atribut Penggilingan Padi Tunas Karya maka akan dikelompokkan atribut-atribut berdasarkan masing-masing kuadran tingkat perbaikan kinerja. Dari analisis data tingkat kepentingan dan kinerja serta nilai rata-rata masing-masing atribut, diperoleh empat kuadran pada diagram kartesius Importance 
Performance Analysis dengan garis pembagi adalah rata-rata tingkat kepentingan atribut yang diharapkan oleh pelanggan dan rata-rata tingkat kinerja atribut yang diterima dan dirasakan oleh pelanggan.

Berdasarkan perhitungan rata-rata tingkat kepentingan dan kinerja masing-masing atribut, maka ke 19 atribut telah dikelompokkan ke dalam 4 Kuadran. Pada kuadran I terdapat 1 atribut yaitu: berperilaku baik pelayan penggilingan padi. Pada kuadran II terdapat 11 atribut yaitu: harga jual jasa penggilingan padi, Harga Jual Sesuai Kualitas, Kemahiran, Keterampilan, Keramahan, Kecepatan Bekerja, Kejujuran, Mendengar masukkan, Penyediaan tempat penjemuran padi, Tekstur, dan Warna. Pada Kuadran III terdapat 4 atribut yaitu: Kecepatan Respon, Diskon, Kesopanan Merespon, Tingkat kebersihan lingkungan Penggilingan Padi. Pada kuadran IV terdapat 3 atribut yaitu: Lokasi, Kecepatan pelayanan (via telpon), Kebersihan beras yang dihasilkan.

Pengelompokan masing-masing atribut pada ke 4 kuadran digunakan untuk memperbaiki kinerja atribut yang dapat mempengaruhi kepuasan pelanggan. Tingkat kepentingan tergantung pada persepsi masing-masing pelanggan sehingga tiap-tiap pelanggan berbeda tingkat kepentingannya. Jadi untuk meningkatkan kepuasan pelanggan dilakukan melalui peningkatan kinerja, dengan pengelompokan Importance Performance Analysis sehingga dapat diketahui atribut mana yang harus menjadi prioritas peningkatan kinerja. Berdasarkan data rata-rata tingkat kepentingan dan kinerja maka ke 19 atribut dikelompokkan ke dalam 4 kuadran, yaitu sebagai berikut: 


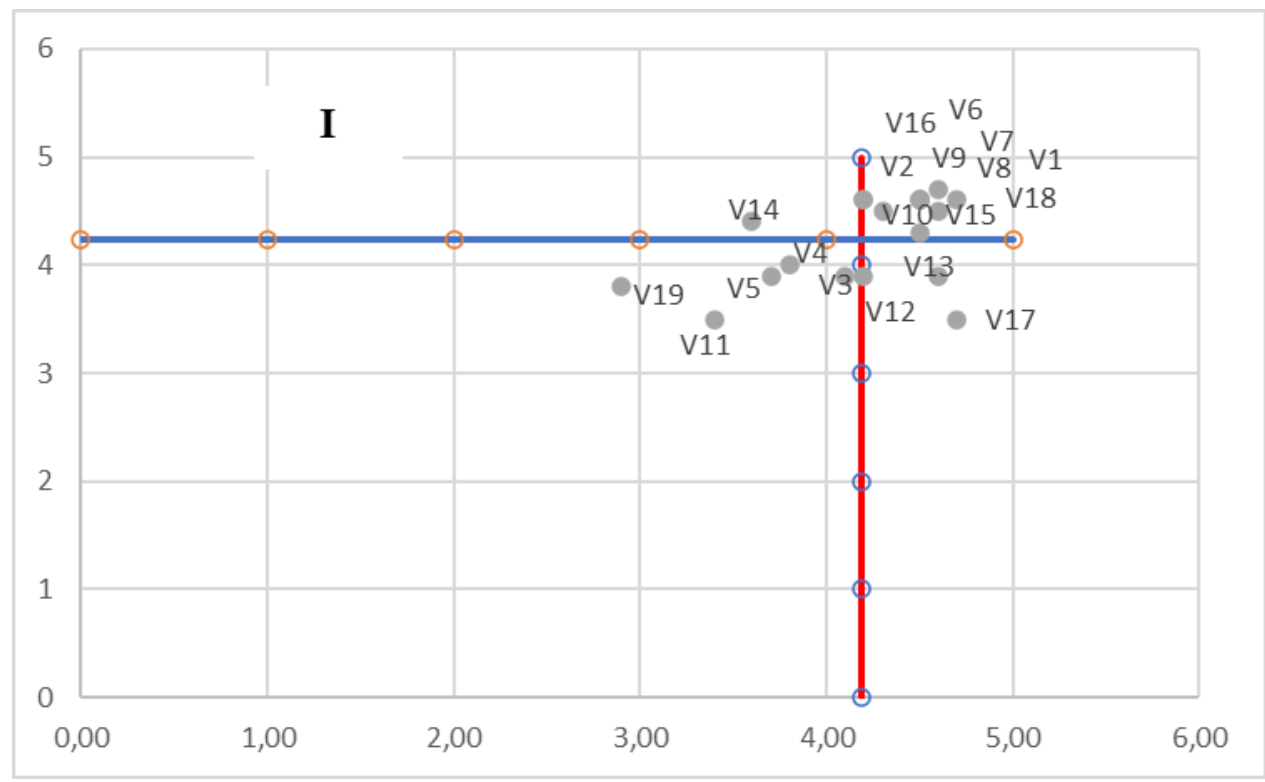

Kinerja Penggilingan Padi Tunas Karya

\section{Gambar 2. Diagram Cartesius Penggilingan Padi Tunas Karya}

Sumber. Referensi (2020), diolah.

Keterangan:

(V1) Harga Jual Jasa Penggilingan Padi

(V2) Harga Jual Sesuai Kualitas

(V3) Kecepatan Respon (sigap)

(V4) Diskon

(V5) Kesopanan Merespon

(V6) Kemahiran

(V7) Keterampilan

(V8) Keramahan

(V9) Kecepatan Bekerja
(V10) Warna

(V11) Tekstur

(V12) Lokasi

(V13) Kecepatan pelayanan (via telpon)

(V14) Berperilaku baik

(V15) Mendengar masukkan

(V16) Kejujuran

(V17) Kebersihan Beras Yang dihasilkan

(V18) Penyediaan tempat penjemuran padi

(V19) Tingkat kebersihan lingkungan

Penggilingan Padi

\section{Kuadran I}

Kuadran I terdapat 1 atribut yaitu: berperilaku baik pelayan penggilingan padi. Atribut ini menjadi prioritas utama bagi manajemen Penggilingan Padi Tunas Karya dalam peningkatan kinerja, karena memiliki nilai kepentingan yang tinggi sementara nilai kinerjanya rendah. Artinya 
pelanggan menganggap atribut berperilaku baik pelayan penggilingan padi penting namun kinerjanya tidak sesuai dengan apa yang diharapkan pelanggan.

Berdasarkan hasil pengamatan di lapangan, pelanggan penggilingan padi melakukan penggilingan dalam waktu yang berbeda - beda yang mana ketika mereka menggiling padi akan berinteraksi dengan petugas yang menggiling padi dan dari sini para pelanggan dapat menilai sikap dan perilaku yang diberikan oleh petugas penggilingan padi agar mereka merasa nyaman untuk melakukan penggunaan jasa dan membuat mereka terus akan memakai jasa penggilingan padi tersebut karena itulah menurut para pelanggan berperilaku baik dalam melayani pengguna jasa itu penting.

Maka hendaknya pihak manajemen Penggilingan Padi Tunas Karya harus melakukan perbaikan kinerja terhadap atribut berperilaku baik dalam melayani pelanggan penggilingan, dengan cara menyesuaikan sikap dalam merespon pelanggan agar pelanggan merasa nyaman dalam melakukan penggunaan jasa dan sesuai dengan kepentingan serta harapan pelanggan sehingga pada akhirnya dapat meningkatkan kepuasan pelanggan.

\section{Kuadran II}

Kuadran II menunjukan bahwa antara tingkat kepentingan dan harapan pelanggan sudah sesuai dengan kinerja masing-masing atribut. Menyatakan pelanggan sudah merasa puas terhadap kinerja atribut-atribut yang mereka terima sehingga usaha Penggilingan Padi Tunas Karya hanya perlu mempertahankan kualitas kinerja yang ada pada kuadran ini, atribut yang ada di kuadrat ini sebanyak 10.

Atribut-atribut yang terdapat pada kuadran ini adalah harga jual jasa penggilingan padi, Harga Jual Sesuai Kualitas, Kemahiran, Keterampilan, Keramahan, Kecepatan Bekerja, Kejujuran, Mendengar masukkan, Penyediaan tempat penjemuran padi, Tekstur, dan Warna. Namun untuk jangka panjang tetap akan diperlukan berbagai peningkatan seiring bermunculannya pesaing-pesaing baru yang turut bersaing dalam memenuhi kepuasan pelanggan. 


\section{Kuadran III}

Kuadran III terdapat 4 atribut yaitu: Kecepatan Respon, Diskon, Kesopanan Merespon, Tingkat kebersihan lingkungan Penggilingan Padi, atribut yang berada diposisi ini dinilai oleh pelanggan tidak terlalu penting, dikarenakan pelanggan tidak terlalu mengharapkan kinerja atribut tersebut dan nyatanya kinerjanya biasa-biasa saja. Dapat dikatakan bahwa atribut kerapian pelayanan memiliki pengaruh yang tidak terlalu besar apabila dilakukan perbaikan kinerjanya.

Berdasarkan hasil pengamatan di lapangan, tenaga kerja Penggilingan Padi Tunas Karya di hadapkan langsung dalam proses menggiling padi. Pada proses tersebut tenaga kerja menggunakan mesin penggilingan untuk menggiling padi menjadi beras dalam proses penggilingan padi, terjadi pemecahan terhadap kulit padi, dilanjutkan pemisahan bulir beras dari kulit, setelah itu dimasukkan kedalam mesin penyosoh yang digunakan untuk membuat beras bersih, selanjutnya memasukkan kedalam mesin pemisah beras yang utuh dan beras yang patah, dan tahap terakhir menggunakan mesin shining yang berfungsi sebagai pencuci dan pembersih beras dan membersihkan lokasi setelah proses penggilingan padi selesai. Untuk perbaikan kinerja atribut pada kuadran ini tidak terlalu penting dilakukan, artinya lebih baik dilakukan perbaikan pada kuadran I (prioritas).

\section{Kuadran IV}

Pada kuadran IV terdapat 3 atribut dinilai oleh pelanggan memiliki kepentingan yang rendah tetapi kinerjanya bagus. Atribut pada kuadran ini adalah yaitu: Lokasi, Kecepatan pelayanan (via telpon), Kebersihan Padi yang dihasilkan. Berdasarkan hasil pengamatan di lapangan masing-masing pelanggan yang menggiling padi di Tunas Karya memiliki tempat tinggal yang berbeda beda lokasinya, sehingga terkadang ada pelanggan yang menggunakan pelayanan via telpon dan ada juga pelanggan yang memilih datang langsung untuk mengetahui padinya sudah selasai digiling atau belum. Lokasi penggilingan padi Tunas Karya yang terletak didalam gang tidak menjadi masalah bagi para pelanggan, dan kebersihan padi yang dihasilkan penggilingan 
tunas karya juga sudah terjamin kebersihannya dan tidak akan mempengaruhi hasil giling.

Pelanggan menganggap atribut Lokasi, Kecepatan pelayanan (via telpon), Kebersihan Padi yang dihasilkan, tidak terlalu penting karena pelanggan merasa meskipun lokasi penggilingan padi terletak dibelakang dari jalan raya, tetapi penggilingan padi menyediakan tempat untuk menjemur padi pelanggan yang belum kering, sehingga pelanggan dapat dengan mudah untuk melakukan penjemuran padi mereka sebelum digiling.

\section{Customer Satisfaction Index (CSI)}

Customer Satisfaction Index (CSI) digunakan untuk mengalisis kepuasan pelanggan secara menyeluruh dari semua atribut-atribut yang diukur. Nilai CSI diperoleh dengan cara membagi Weigthted Average (penjumlahan seluruh Weighted Score) dengan skala maksimum (skala 5) yang digunakan dalam penelitian ini. Nilai CSI pada penelitian ini adalah 0,85, menurut Panduan Survei Kepuasan Pelanggan yang berada direntang 0,81 - 1,00 artinya pelanggan Penggilingan Padi Tunas Karya secara keseluruhan berdasarkan kinerja dan kepentingan atribut-atribut produk berada pada kriteria "sangat puas" yang ditunjukkan dengan angka hasil 0,85. Customer Satisfaction Index (CSI) digunakan untuk tujuan menganalisis kepuasan pelanggan secara menyeluruh dari semua atribut-atribut yang diukur. Hasil dari analisis Customer Satisfaction Index (CSI) secara rinci dapat dilihat pada Tabel 4 berikut: 
Tabel 4. Analisis Customer Satisfaction Index (CSI) Penggilingan Penggilingan Padi Tunas Karya

\begin{tabular}{|c|c|c|c|c|c|}
\hline No & Atribut & $\begin{array}{l}\text { Kepentin } \\
\text { gan }\end{array}$ & $\begin{array}{l}\text { Importance } \\
\text { Weighting } \\
\text { Factors (\%) }\end{array}$ & Kinerja & $\begin{array}{c}\text { Weighted } \\
\text { Score }\end{array}$ \\
\hline 1 & Harga Jasa Penggilingan Padi & 4.2 & 5.28 & 4.6 & 0.24 \\
\hline 2 & Harga Seusai Kualitas & 4.6 & 5.78 & 4.7 & 0.27 \\
\hline 3 & $\begin{array}{ll}\text { Kecepatan } & \text { Pelayanan } \\
\text { Merespon (sigap) } & \end{array}$ & 4.1 & 5.15 & 3.9 & 0.20 \\
\hline 4 & Memberikan Potongan Harga & 3.8 & 4.77 & 4.0 & 0.19 \\
\hline 5 & Memberikan Respon Sopan & 3.7 & 4.65 & 3.9 & 0.18 \\
\hline 6 & $\begin{array}{l}\text { Kemahiran } \\
\text { Penggilingan }\end{array}$ & 4.5 & 5.65 & 4.3 & 0.24 \\
\hline 7 & $\begin{array}{l}\text { Keterampilan dalam } \\
\text { pengerjaan }\end{array}$ & 4.5 & 5.65 & 4.6 & 0.26 \\
\hline 8 & Keramahan dalam Melayani & 4.5 & 5.65 & 4.6 & 0.26 \\
\hline 9 & Kecepatan dalam Pengerjakan & 4.5 & 5.65 & 4.6 & 0.26 \\
\hline 10 & Warna Beras yang dihasilkan & 4.7 & 5.90 & 4.6 & 0.27 \\
\hline 11 & Tekstur Beras yang dihasilkan & 3.4 & 4.27 & 3.5 & 0.15 \\
\hline 12 & Lokasi Penggilingan Padi & 4.2 & 5.28 & 3.9 & 0.21 \\
\hline 13 & Pelayanan Via Telpon & 4.6 & 5.78 & 3.9 & 0.23 \\
\hline 14 & $\begin{array}{l}\text { Memberikan respon tutur kata } \\
\text { yang baik }\end{array}$ & 3.6 & 4.52 & 4.4 & 0.20 \\
\hline 15 & Mendengarkan masukkan & 4.3 & 5.40 & 4.5 & 0.24 \\
\hline 16 & Kejujuran dalam pelayanan & 4.2 & 5.28 & 4.6 & 0.24 \\
\hline 17 & $\begin{array}{l}\text { kebersihan beras yang } \\
\text { dihasilkan }\end{array}$ & 4.7 & 5.90 & 3.5 & 0.21 \\
\hline 18 & $\begin{array}{l}\text { Penyediaan } \\
\text { penjemuran }\end{array}$ & 4.6 & 5.78 & 4.5 & 0.26 \\
\hline 19 & $\begin{array}{l}\text { Kebersihan } \\
\text { penggilingan }\end{array}$ & 2.9 & 3.64 & 3.8 & 0.14 \\
\hline & Total & 79.6 & 100 & 80.4 & 4.25 \\
\hline \multicolumn{5}{|c|}{ Customer satisfaction Index (\%) } & 0.85 \\
\hline
\end{tabular}

Sumber: referensi (2020), diolah. 
Nilai Customer Satisfaction Index (CSI) kepuasan pelanggan Penggilingan Padi Tunas Karya untuk keseluruhan dilihat berdasarkan penilaian kinerja dan kepentingan atribut-atribut yang diterima oleh pelanggan menunjukan angka Customer Satisfaction Index (\%) sebesar 0,85. Dengan hasil ini menunjukan jika pelanggan penggilingan padi sangat puas terhadap pelayanan dan produk yang dihasilkan dan diberikan penggilingan padi Tunas Karya, dan membuat mereka akan terus bertahan menggunakan jasa penggilingan padi Tunas Karya.

Perhitungan analisis CSI kepuasan pelanggan Penggilingan Padi Tumas Karya yang berada dikriteria "sangat puas", untuk kepuasan pelanggan baiknya terus ditingkatkan hingga mencapai taraf maksimal yang diindikasikan dengan nilai CSI mendekati angka 1,00 akan lebih baik, pelanggan akan benar-benar merasakan kinerja atribut-atribut Penggilingan Padi Tugas Karya sama dengan tingkat kepentingan yang pelanggan harapkan. Kepuasan sangat berhubungan dengan loyalitas, karena itu ketika pelanggan merasa puas maka mereka akan loyal terhadap usaha jasa Penggilingan Padi Tunas Karya.

\section{KESIMPULAN DAN REKOMENDASI KEBIJAKAN}

\section{Kesimpulan}

Berdasarkan Importance Performance Analysis (IPA) atribut yang diteliti masuk ke dalam empat kuadran. kuadran I terdapat 1 atribut yaitu: berperilaku baik pelayan penggilingan padi. Pada kuadran II terdapat 11 atribut yaitu: harga jual jasa penggilingan padi, harga jual sesuai kualitas, kemahiran, keterampilan, keramahan, kecepatan bekerja, kejujuran, mendengar masukkan, penyediaan tempat penjemuran padi, tekstur, dan warna. Pada Kuadran III terdapat 4 atribut yaitu: kecepatan respon, diskon, kesopanan merespon, tingkat kebersihan lingkungan penggilingan padi. Pada kuadran IV terdapat 3 atribut yaitu: lokasi, kecepatan pelayanan (via telpon), kebersihan beras yang dihasilkan. Berdasarkan Customer Satisfaction Index (CSI) secara keseluruhan pelanggan sangat puas terhadap kinerja Penggilingan Padi Tunas Karya hal ini terlihat dari nilai Customer Satisfaction Index (CSI) yaitu sebesar 0,85 yang berada pada rentang $0,81-1,00$. 


\section{Rekomonedasi Kebijakan}

1. Atribut perilaku penggilingan padi hendaknya terus meningkatkan kinerjanya,

2. Pertahankan kinerja terutama harga jual jasa penggilingan padi, harga jual sesuai kualitas, kemahiran, keterampilan, keramahan, kecepatan bekerja, kejujuran, mendengar masukkan, penyediaan tempat penjemuran padi, tekstur, dan warna.

3. Terus melakukan evaluasi kepuasan terhadap pelanggan secara bertahap untuk menindak lanjuti keluhan-keluhan yang didapat dari pelanggan terhadap kualitas pelayanan Penggilingan Padi

\section{UCAPAN TERIMAKASIH}

Ucapan terimakasih kepada semua pihak yang sudah berpartisipasidalam penelitian ini serta para petani penggilingan padi Tunas Karya Desa persil Raya Kecamatan Seuryan Hilir Kabupaten Kuala Pembuang Kalimantan Tengah.

\section{DAFTAR PUSTAKA}

Arsyad, M., Junaedi, M., Mulyati, dan Tahir, M. 2015. Evaluasi Kualitas beras dan Unit Cost Penggiling Padi untuk Varietas dan Ciliwung. Journal Ilmiah Indonesia. 10(1).

Ariani, D. Wahyu. 2009. Manajemen Operasi Jasa. Yogyakarta : Graha Ilmu.

Limbong Ismail., Mozart B Darus, dan Emalisa. (2015). Analisis Kelayakan Usaha Penggilingan Padi Skala Kecil (Studi Kasus: Kecamatan Tanjung Morawa, Kabupaten Deli Serdang, Provinsi Sumatera Utara). Journal on social economic of agriculture and agribusiness, 4(12).

Umar, Sudirman. 2011. Pengaruh Sistim Penggilingan Padi Terhadap Kualitas Giling di Sentra Produksi Beras Lahan Pasang Surut. Jurnal Teknologi Pertanian. Universitas Mulawarman. Volume 7 No 1.

Warisno Wowon, Tamrin, dan Budianto Lanya. (2014). Analisis Mutu Beras Pada Mesin Penggilingan Padi Berjalan di Kabupaten Pringsewu.

Yuliarmi, Ni Nyoman dan Putu Riyasa. 2007. Analisis Faktor-Faktor Yang Mempengaruhi Kepuasan Pelanggan Terhadap Pelayanan PDAM Kota Denpasar. Denpasar: Buletin Studi Ekonomi Volume 12 Nomor 1 Tahun 2007. 